\title{
is Research Square \\ Optic Neuropathy after COVID-19 Vaccination: Case Report and Systematic Review
}

\author{
Abid Haseeb \\ University of Illinois Chicago Department of Ophthalmology and Visual Sciences \\ Abdelrahman M. Elhusseiny \\ University of Arkansas for Medical Sciences \\ Ayman Elnahry ( $\sim$ ayman_elnahri@hotmail.com ) \\ Cairo University https://orcid.org/0000-0001-5148-316X
}

\section{Systematic Review}

Keywords: CNS inflammation, COVID-19, ischemic optic neuropathy, ocular inflammation, optic neuropathy, vaccination

Posted Date: February 2nd, 2022

DOI: https://doi.org/10.21203/rs.3.rs-1299812/v1

License: (c) (i) This work is licensed under a Creative Commons Attribution 4.0 International License. Read Full License 


\section{Abstract \\ Purpose:}

To report a case of anterior ischemic optic neuropathy (AION) following COVID-19 vaccination and provide a systematic review of all published cases of optic neuropathy following COVID-19 vaccination.

\section{Methods:}

A systematic literature search was performed using PubMed and Ovid MEDLINE for cases of optic neuropathy following COVID-19 vaccination. Terms used in the search included "COVID-19 vaccination", "optic neuropathy", "optic neuritis", and "ischemic optic neuropathy". Titles and abstracts were initially screened then full texts of eligible studies were reviewed for data extraction. Only cases published in the English language, peer reviewed, and that included details on optic nerve involvement were included. All study types were eligible for inclusion.

\section{Results:}

Including our patient, a total of 10 patients (8 females) were identified as developing optic neuropathy following COVID19 vaccination. Five patients (50.0\%) were diagnosed with AION, while 4 (40.0\%) were diagnosed with optic neuritis. One patient was diagnosed with papillitis and neuroretinitis. Three patients (30.0\%) had bilateral involvement. Mean age of patients was $48.5 \pm 19.7$ years. Mean time from vaccination to onset of ophthalmic symptoms was $6.5 \pm 6.4$ days. Mean presenting visual acuity was logMAR $0.598 \pm 0.621$ (20/79, Snellen). For the 8 eyes which had both presenting and final follow-up visual acuity, mean presenting vision was logMAR $0.369 \pm 0.420(20 / 47)$ and at final follow-up was $0.114 \pm 0.261(20 / 26 ; P=0.184)$.

\section{Conclusion:}

COVID-19 vaccination may result in optic neuropathy in the form of optic neuritis and ischemic optic neuropathy. Further studies are needed to determine the incidence, management, and prognosis of optic neuropathies associated with COVID-19 vaccination.

\section{Introduction}

During 2021, vaccination against severe acute respiratory failure coronavirus 2 (SARS-CoV-2) emerged as a primary focus of public health efforts to mitigate the COVID-19 pandemic. Although generally found to be safe and effective in several large clinical trials, COVID-19 vaccines have been the subject of considerable scrutiny and analysis since the time of their introduction into the public sphere.

COVID-19 disease itself has impacted patient vision in numerous ways. Previous research has demonstrated a link between COVID-19 infection and ocular complications, direct or indirect. It has been reported that inflammatory conditions such as conjunctivitis, scleritis, orbital inflammatory disease, keratoconjunctivitis and retinal involvement may occur in COVID-19 infection [1-9]. In terms of indirect impact, Elhusseiny et al. and Salanha et al. reported on the impact of increased screen time and its relationship with eye strain and dry eye symptoms in pediatric and adult populations, respectively $[7,10]$. 
Since their introduction, COVID-19 vaccines have been associated with an assortment of ophthalmologic manifestations [11, 12]. Separately, these events have included orbital [13], corneal [14, 15], uveitic [16, 17], neuroophthalmologic [18, 19], retinal [20, 21], and thrombotic [22] events. Regarding neuro-ophthalmologic manifestations in particular, several cranial nerve palsies have been reported, including oculomotor [23], abducens [24], and facial (Bell's) nerve palsy [25-28]. To date, a limited number of reports have been made of optic neuropathy following COVID-19 vaccination [19, 29-33], and a few of them have been designated as anterior ischemic optic neuropathy (AION); three non-arteritic (NAION) [29, 30, 32], and one arteritic (AAION) [34]. In this report, we describe a case of ischemic optic neuropathy following vaccination with the BNT162b2 COVID-19 vaccination (Pfizer-BioNTech, New York, NY), discuss the pathophysiology for the development of optic nerve ischemia following vaccination, and provide a systematic review of all cases of optic neuropathy following COVID-19 vaccination published to date.

\section{Methods}

A systematic literature search was performed using PubMed and Ovid MEDLINE on January 20, 2022, for cases of optic neuropathy following COVID-19 vaccination. Terms used in the search included "COVID-19 vaccination", "optic neuropathy", "optic neuritis", "papillitis", "retrobulbar optic neuritis", "ischemic optic neuropathy", and "neuroretinitis". Titles and abstracts were initially screened for identification of studies, then full texts were retrieved for eligible studies for review and possible inclusion in the final analysis. References of identified studies were also screened for eligible studies for inclusion. Only cases that were published in the English language, peer reviewed, and that included details on optic nerve involvement were included. There were no restrictions on study type, and all studies, including case reports and case series, were eligible for inclusion. Exclusion criteria included insufficient evidence or details of optic nerve involvement.

\section{Data extraction and Statistical analysis}

The following data was extracted from included studies: patient age, sex, vaccine type, vaccination dose, duration between vaccination and onset of ocular symptoms, presenting and final visual acuity, presenting symptoms, diagnoses, and treatment course. For continuous variables, mean was reported as mean \pm one standard deviation. Comparisons of populations were made, when appropriate, using a two-tailed two-sample t-test for means. $\mathrm{P}<0.05$ was considered statistically significant.

\section{Results}

Including our patient, a total of 10 patients (8 female, 2 male) were identified as developing optic neuropathy following COVID-19 vaccination (Table 1). Five patients (50.0\%) were diagnosed with AION, while 4 patients $(40.0 \%)$ were diagnosed with optic neuritis. One patient was diagnosed with papillitis in one eye and neuroretinitis in the other. Another two patients (30.0\% in total) also had bilateral involvement, one with bilateral AAION and the other with bilateral optic neuritis. The mean age for all patients was $48.5 \pm 19.7$ years (Range: $19-79$ years). The mean age for AION patients was $61 \pm 14.5$ years (Range: 40 -79 years), while the mean age for optic neuritis patients was $27.8 \pm 6.1$ years (Range: 19-32 years) $(P=0.004)$. The mean time from vaccination to onset of ophthalmic symptoms was $6.5 \pm 6.4$ days (Range: 0-21 days). For the 10 patients (13 eyes) found to have optic neuropathy following COVID-19 vaccination, the mean presenting visual acuity was logMAR $0.598 \pm 0.621$ (20/79 in Snellen notation). For the 8 eyes which had both presenting and final follow-up visual acuity, the mean presenting visual acuity was logMAR $0.369 \pm 0.420(20 / 47$ in Snellen notation) and at final follow-up was $0.114 \pm 0.261$ (20/26 in Snellen notation; $P=0.184)$. For the 4 cases with NAION (4 eyes), the mean presenting visual acuity was logMAR $0.475 \pm 0.370$ (20/59 in Snellen notation), comparable 
to the 4 patients ( 5 eyes) with optic neuritis, who had mean presenting visual acuity of logMAR $0.396 \pm 0.416(20 / 49$ in Snellen notation). 
Table 1

Summary of reports of optic neuropathies following COVID-19 vaccination.

\begin{tabular}{|c|c|c|c|c|c|c|c|c|}
\hline Author & Age & Sex & Vaccine & $\begin{array}{l}\text { Time from } \\
\text { Vaccine to } \\
\text { Symptoms } \\
\text { (days) }\end{array}$ & $\begin{array}{l}\text { Presenting } \\
\text { VA }\end{array}$ & Side & Manifestations & Outcome \\
\hline $\begin{array}{l}\text { Current } \\
\text { Study }\end{array}$ & 40 & $M$ & $\begin{array}{l}\text { BNT162b2, } \\
\# 1\end{array}$ & 4 & $20 / 40$ & os & $\begin{array}{l}\text { Vision loss OS, } \\
\text { with exam } \\
\text { revealing } \\
\text { RAPD OS and } \\
\text { a swollen, pale } \\
\text { optic disc with } \\
\text { blurred edges } \\
\text { and splinter } \\
\text { hemorrhages. } \\
\text { FA with early } \\
\text { leakage OS } \\
\text { with late } \\
\text { staining, OCT } \\
\text { with disc } \\
\text { edema. NAION } \\
\text { OS was } \\
\text { diagnosed. }\end{array}$ & $\begin{array}{l}\text { Control of systemic } \\
\text { risk factors led to } \\
\text { improvement of the } \\
\text { optic disc swelling } \\
\text { with pallor and } \\
\text { minimal visual field } \\
\text { improvement. }\end{array}$ \\
\hline \multirow[t]{3}{*}{$\begin{array}{l}\text { Elnahry } \\
\text { et al. } \\
2021\end{array}$} & 69 & $\mathrm{~F}$ & $\begin{array}{l}\text { BNT162b2, } \\
\text { \#2 }\end{array}$ & 16 & $\mathrm{CF}$ & OD & \multirow{2}{*}{$\begin{array}{l}\text { Blurry vision } \\
\text { OU with } \\
\text { immediate OS } \\
\text { clearing but } \\
\text { persistent } \\
\text { blurring OD. } \\
\text { Examination } \\
\text { with optic } \\
\text { nerve head } \\
\text { edema } \\
\text { (OD>OS) and } \\
\text { RAPD OD on } \\
\text { exam. RNFL } \\
\text { imaging } \\
\text { confirmed a } \\
\text { diagnosis of } \\
\text { CNS } \\
\text { inflammatory } \\
\text { syndrome with } \\
\text { neuroretinitis. }\end{array}$} & \multirow[t]{2}{*}{$\begin{array}{l}\text { Significant } \\
\text { improvement } \\
\text { including decreased } \\
\text { optic nerve swelling } \\
\text { after } 5 \text { days of IV } \\
\text { methylprednisolone. }\end{array}$} \\
\hline & & & & & $20 / 20$ & os & & \\
\hline & 32 & $\mathrm{~F}$ & $\begin{array}{l}\text { CoviShield, } \\
\# 1\end{array}$ & 4 & $20 / 30$ & OS & $\begin{array}{l}\text { Blurred vision } \\
\text { with superior } \\
\text { field defect OS. } \\
\text { Examination } \\
\text { revealed left } \\
\text { optic disc } \\
\text { swelling and } \\
\text { RAPD with } \\
\text { decreased } \\
\text { RNFL } \\
\text { thickness. MRI } \\
\text { was diagnostic } \\
\text { of left optic } \\
\text { neuritis. }\end{array}$ & $\begin{array}{l}\text { Significant } \\
\text { improvement } \\
\text { including decreased } \\
\text { optic nerve swelling } \\
\text { after } 3 \text { days of IV } \\
\text { methylprednisolone } \\
\text { followed by PO } \\
\text { prednisone. }\end{array}$ \\
\hline $\begin{array}{l}\text { Leber et } \\
\text { al. } 2021\end{array}$ & 32 & $\mathrm{~F}$ & $\begin{array}{l}\text { Corona } \\
\text { Vac, \#2 }\end{array}$ & 0 & $20 / 200$ & os & $\begin{array}{l}\text { Rapidly } \\
\text { progressive } \\
\text { worsening } \\
\text { vision and } \\
\text { pain with EOM } \\
\text { OS. }\end{array}$ & $\begin{array}{l}\text { Improvement in } \\
\text { symptoms and } \\
\text { vision following } 5 \\
\text { days of IV } \\
\text { methylprednisolone } \\
1 \mathrm{~g} \text { and intravenous }\end{array}$ \\
\hline
\end{tabular}




\begin{tabular}{|c|c|c|c|c|c|c|c|c|}
\hline \multirow[t]{3}{*}{ Author } & \multirow[t]{3}{*}{ Age } & \multirow[t]{3}{*}{ Sex } & \multirow[t]{3}{*}{ Vaccine } & \multirow[t]{3}{*}{$\begin{array}{l}\text { Time from } \\
\text { Vaccine to } \\
\text { Symptoms } \\
\text { (days) }\end{array}$} & $\begin{array}{l}\text { Presenting } \\
\text { VA }\end{array}$ & Side & Manifestations & Outcome \\
\hline & & & & & & & \multirow{2}{*}{$\begin{array}{l}\text { Examination } \\
\text { revealed RAPD } \\
\text { OS and disc } \\
\text { swelling OD } \\
\text { and OS. Labs } \\
\text { revealed } \\
\text { thyroiditis and } \\
\text { MRI revealed } \\
\text { bilateral optic } \\
\text { neuritis. }\end{array}$} & \multirow[t]{2}{*}{$\begin{array}{l}\text { corticosteroid } \\
\text { therapy to reduce } \\
\text { TSH level. }\end{array}$} \\
\hline & & & & & $20 / 20$ & OD & & \\
\hline \multirow{2}{*}{$\begin{array}{l}\text { Maleki } \\
\text { et al. } \\
2021\end{array}$} & \multirow[t]{2}{*}{79} & \multirow[t]{2}{*}{$\mathrm{F}$} & \multirow{2}{*}{$\begin{array}{l}\text { BNT162b2, } \\
\text { \#2 }\end{array}$} & \multirow[t]{2}{*}{2} & $20 / 1250$ & OD & \multirow[b]{2}{*}{$\begin{array}{l}\text { Bilateral } \\
\text { sudden loss of } \\
\text { vision, OD>OS, } \\
\text { with } 3+ \\
\text { afferent } \\
\text { pupillary } \\
\text { defect OD. } \\
\text { OCT, FA, and } \\
\text { ICG consistent } \\
\text { with } \\
\text { generalized } \\
\text { disc pallor OD } \\
\text { and inferior } \\
\text { pallor OS, } \\
\text { consistent with } \\
\text { bilateral } \\
\text { arteritic } \\
\text { anterior } \\
\text { ischemic optic } \\
\text { neuropathy } \\
\text { (AAION). }\end{array}$} & \multirow{2}{*}{$\begin{array}{l}\text { Patient was } \\
\text { initiated on } \\
\text { subcutaneous } \\
\text { tocilizumab } 162 \mathrm{mg} \\
\text { weekly. Results } \\
\text { were NR. }\end{array}$} \\
\hline & & & & & $20 / 40$ & OS & & \\
\hline $\begin{array}{l}\text { Pawar } \\
\text { et al. } \\
2021\end{array}$ & 28 & $\mathrm{~F}$ & NR & 21 & $20 / 120$ & OS & $\begin{array}{l}\text { Sudden vision } \\
\text { loss OS, with } \\
\text { examination } \\
\text { revealing mild } \\
\text { blurring of the } \\
\text { optic disc } \\
\text { margin. MRI } \\
\text { was consistent } \\
\text { with optic } \\
\text { neuritis. }\end{array}$ & $\begin{array}{l}\text { Resolution of } \\
\text { symptoms after IV } \\
\text { methylprednisolone } \\
\text { followed by PO } \\
\text { steroid course. }\end{array}$ \\
\hline $\begin{array}{l}\text { Nachbor } \\
\text { et al. } \\
2021\end{array}$ & 64 & $F$ & $\begin{array}{l}\text { BNT162b2, } \\
\# 1\end{array}$ & 6 & $20 / 80$ & OS & $\begin{array}{l}\text { Acute, } \\
\text { painless, } \\
\text { unilateral } \\
\text { vision loss } \\
\text { with superior } \\
\text { sectoral optic } \\
\text { disc edema OS } \\
\text { after 1st dose. } \\
\text { After 2nd dose, } \\
\text { VA was CF } \\
\text { with persistent } \\
\text { APD OS. RNFL } \\
\text { OCT showed } \\
\text { diffuse } \\
\text { thickening OS. } \\
\text { NAION was } \\
\text { diagnosed. }\end{array}$ & $\begin{array}{l}\text { Improvement of } \\
\text { symptoms with PO } \\
\text { prednisone } \\
1 \mathrm{mg} / \mathrm{kg} / \text { day over } \\
\text { one week. } \\
\text { Resolution of optic } \\
\text { disc edema OS and } \\
\text { diffuse pallor of } \\
\text { optic nerve OS. }\end{array}$ \\
\hline
\end{tabular}




\begin{tabular}{|c|c|c|c|c|c|c|c|c|}
\hline $\begin{array}{l}\text { Tsukii } \\
\text { et al. } \\
2021\end{array}$ & 55 & $F$ & $\begin{array}{l}\text { BNT162b2, } \\
\# 1\end{array}$ & 3 & $20 / 20$ & OD & $\begin{array}{l}\text { Visual disturbance with RAPD } \\
\text { OD. Fundoscopy revealed } \\
\text { diffuse optic disc swelling OD } \\
\text { which was confirmed on OCT. } \\
\text { Goldmann visual field testing } \\
\text { revealed an inferior visual field } \\
\text { defect OD. A diagnosis of } \\
\text { NAION was made. }\end{array}$ & $\begin{array}{l}\text { No treatment was } \\
\text { initiated. At a two- } \\
\text { month follow-up, } \\
\text { vision remained } \\
\text { normal and there } \\
\text { was diffuse pallor } \\
\text { of the right eye. }\end{array}$ \\
\hline $\begin{array}{l}\text { Garcia- } \\
\text { Estrada } \\
\text { et al. } \\
2021\end{array}$ & 19 & $\mathrm{~F}$ & $\begin{array}{l}\text { Ad26.COV2.S, } \\
\# 1\end{array}$ & 7 & $20 / 20$ & $O D$ & $\begin{array}{l}\text { Ocular pain and vision loss } \\
\text { OS, with examination } \\
\text { revealing amaurosis, APD, and } \\
\text { papillitis, all OS. Diagnosis of } \\
\text { optic neuritis was made. }\end{array}$ & $\begin{array}{l}\text { Resolution of } \\
\text { symptoms and } \\
\text { papillitis with five } \\
\text { days of IV } \\
\text { methylprednisolone } \\
\text { followed by a PO } \\
\text { prednisolone taper. }\end{array}$ \\
\hline $\begin{array}{l}\text { Girbardt } \\
\text { et al. } \\
2021\end{array}$ & 67 & $M$ & Vaxveria, \#1 & 2 & $20 / 200$ & $O D$ & $\begin{array}{l}\text { Decreased vision and } \\
\text { scotomas OD with } \\
\text { examination revealing an } \\
\text { elevated, congested optic } \\
\text { nerve head with surrounding } \\
\text { intraretinal hemorrhages and } \\
\text { cotton-wool spots and } \\
\text { probable intraretinal fluid. OCT } \\
\text { consistent with NAION. }\end{array}$ & NR \\
\hline \multicolumn{9}{|c|}{ 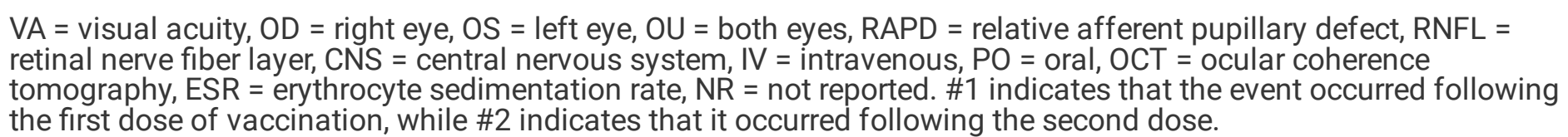 } \\
\hline
\end{tabular}

\section{Case Report}

A 40-year-old male patient presented to us with acute-onset diminution of vision in his left eye of stationary course for 5 days. He also complained of an inferior visual field defect. Nine days earlier, he had received his first dose of the BNT162b2 COVID-19 vaccination (Pfizer-BioNTech, New York, NY) which was followed by mild constitutional symptoms including mild fever and myalgias which were treated with acetaminophen. His past medical history included type 2 diabetes mellitus for 7 years treated by oral hypoglycemic drugs and diet. His last $\mathrm{HbA} 1 \mathrm{C}$ was $7.8 \%$. Examination revelated a best corrected visual acuity of 20/20 in the right eye (OD) and 20/40 in the left eye (OS). There was a left relative afferent pupillary defect. External ocular exam, ocular motility and balance, intraocular pressure, and anterior segment examination was normal in both eyes. Posterior segment examination OS revealed a swollen, pale optic disc with blurred edges and splinter hemorrhages (Figure 1A). Posterior segment exam OD was normal. Fluorescein angiography was performed and showed early leakage from the left optic disc with late staining and few microaneurysms (Figure 1B). Optical coherence tomography (OCT) allowed quantitative analysis of disc edema (Figure 2A). OCT angiography was done and showed peripapillary flow void areas OS indicating mild ischemia (Figure 2B). Visual field testing revealed an inferior altitudinal field defect OS (Figure 3) and normal visual field OD. Magnetic resonance (MR) imaging of the brain and cervical spine with contrast as well as MR venography were unrevealing.

The patient underwent extensive laboratory investigations including complete blood count, erythrocyte sedimentation rate, C-reactive protein, angiotensin converting enzyme levels, interferon gamma release essays for tuberculosis, rapid plasma reagin, anti-nuclear antibodies, anti-dsDNA antibodies, anti-neutrophil cytoplasmic antibodies, and antiaquaporin-4 antibodies which were all normal. SARS-CoV-2 PCR was negative, and a chest x-ray was normal. Lumbar puncture was performed and revealed a normal cerebrospinal fluid opening pressure with normal analysis. The patient was diagnosed with left anterior ischemic optic neuropathy secondary to COVID-19 vaccination. He was prescribed low 
dose aspirin and referred for more strict control of his blood sugar levels and cardiovascular systemic risk factors. Follow-up over 2 months revealed improvement of the optic disc swelling with pallor and minimal visual field improvement.

\section{Discussion}

Anterior ischemic optic neuropathy is an important cause of vision loss in adults divided into arteritic (AAION) and nonarteritic (NAION) categories. Previously, the incidences per 100,000 individuals for NAION and AION, respectively, were reported as 2.30 and 0.36 [35]. In terms of pathogenesis, AAION results from inflammatory changes and thrombosis of the short posterior ciliary arteries, which causes infarction of the optic nerve head [36, 37]. AAION is an ophthalmic emergency and treatment with systemic corticosteroids is standard [36]. NAION is typically idiopathic [36], though there is an association with sleep apnea syndrome [38-40], medications including interferon alpha and sildenafil [41-43], and the presence of optic disc drusen [44-46]. It commonly presents with an altitudinal field defect. Post-vaccination NAION has also been previously reported following influenza vaccination $[47,48]$.

Previous studies have demonstrated a female predominance of incident optic neuritis, with one large study in the United Kingdom demonstrating that $69.4 \%$ of new cases over 22 years were in females [49]. However, Lee et al. previously demonstrated in a cohort of diabetic patients that male gender increases the risk of developing AION by $32 \%$ [50].

Optic neuropathy has been reported rarely in the literature following vaccination against COVID-19. Only a total of 8 reports on 9 patients have been published to date, 8 (88.9\%) of whom were females (Table 1). The currently reported case is the second case of post-COVID-19 vaccination optic neuropathy in a male, and the first case of post-BNT162b2 COVID-19 vaccine (Pfizer-BioNTech) optic neuropathy in a male. In a relatively large multinational study of ocular inflammatory events following COVID-19 vaccination, 70 patients were reported to develop ocular inflammation within 14 days of COVID-19 vaccination, but only 2 (2.9\%) patients were diagnosed with optic neuritis [51]. This indicates that the incidence of optic neuropathy following COVID-19 vaccination could be low. The latter study, however, did not provide specific details on cases with optic nerve involvement. Elnahry et al. previously reported on a pair of patients, one of whom was a 69-year-old woman who developed CNS inflammatory syndrome with neuroretinitis and papillitis following vaccination with the BNT162b2 COVID-19 vaccine (Pfizer-BioNTech), and the other of whom was a 32-yearold woman who developed retrobulbar optic neuritis following vaccination with the CoviShield COVID-19 vaccine (AstraZeneca/University of Oxford, Cambridge, UK) [19]. Only the patient who developed retrobulbar optic neuritis demonstrated significant improvement with IV methylprednisolone. Elsewhere, Leber et al. [31], Pawar et al. [33], and Garcia-Estrada et al. [29] all reported cases of optic neuritis in women aged 32, 21, and 19, respectively. All three patients demonstrated improvement with IV methylprednisolone therapy.

The remaining cases reported in the literature were cases of AAION or NAION. Nachbor et al. reported on a 64-year-old woman who developed acute, unilateral vision loss 6 days after receiving her first dose of the BNT162b2 vaccine [32]. Examination revealed superior sectoral optic disc edema at that time. While waiting for ophthalmologic follow-up, the patient received her second dose of the vaccine three weeks after her first dose. She awoke the next morning with painless, near-complete vision loss, with visual acuity on presentation being counting fingers at 2 feet. Examination revealed peripapillary splinter hemorrhages in the optic nerve OS and Humphrey visual field testing revealed dense constriction OS. OCT showed diffuse thickening of the retinal nerve fiber layer OS. All examination findings were normal OD. The patient was diagnosed with NAION and treated with one week of oral prednisone $1 \mathrm{mg} / \mathrm{kg} / \mathrm{day}$. At a six-week follow-up, visual acuity was 20/100 OS with resolved optic disc edema replaced by diffuse pallor, consistent with NAION. 
Tsukii et al. reported on a 55-year-old woman who presented with visual field disturbance which developed three days after the first dose of the BNT162b2 vaccine [52]. Although VA was 20/20 OD and OS at presentation, fundoscopy revealed diffuse optic disc swelling and Goldmann visual field testing revealed an inferior visual field defect. A diagnosis of NAION was made. The patient received no treatment. At follow-up, vision remained unchanged and there was only residual diffuse optic nerve pallor.

We have previously described that an autoimmune mechanism underlies the development of optic neuropathies following vaccination [11]. Previously, Stübgen et al. reported that there is no long-term risk of developing optic neuropathy following vaccination, but that the presence of adjuvants contributes to the process [53]. However, in the absence of adjuvants in several of the COVID-19 vaccines, this explanation is insufficient [19]. Clinically, it is challenging to differentiate between AION and optic neuritis, and the diagnosis is usually based on both clinical impression and multimodal imaging findings [54-56]. Some differentiating features include an older age of onset, altitudinal visual field defect, and worse visual outcome in patients with AION which was also found in our study, however, these features cannot confidently distinguish between both conditions [54]. Furthermore, the pathophysiology (and treatment) of both types of optic neuropathies is postulated to be different and it is not currently clear why some patients develop AION while others develop optic neuritis following vaccination. Documented risk factors for NAION include diabetes, small cup-to-disc ratio, hyperlipidemia, and hypertension and it is likely that the development of NAION is a multifactorial process which includes pre-existing structural compromise of the optic nerve $[36,57,58]$.

Our patient had the risk factor of type 2 diabetes, and the transient pro-inflammatory and hypercoagulable state following vaccination may have led to the development of AION. Nachbor et al. also endorsed this hypothesis for their patient with NAION [32]. Tsukii et al. also proposed that neutralizing antibodies directed against SARS-CoV-2 spike proteins after vaccination may cross-react with proteins in the retinal vasculature and retinal pigment epithelial cells, a mechanism also endorsed by Maleki et al [34, 52]. It is conceivable that both processes may have played a role in the development of AION in our patient. Another possible explanation for the development of post-vaccination optic neuropathy that could link the occurrence of inflammation and ischemia was recently elucidated by Francis and colleagues in patients developing optic neuropathy in association with immune checkpoint inhibitors used for cancer treatment [59]. These immunotherapy agents, like vaccines, enhance the adaptive immune response which may result in a range of adverse inflammatory events including ophthalmic and neurologic phenomenon [59]. Francis and colleagues indicated that this class of drugs may result in optic papillitis, a specific type of optic neuritis that involves inflammation of the optic nerve head, leading to ischemia of the optic nerve head and a picture similar to AION [59,60].

In conclusion, several cases of optic neuropathy have been reported following the administration of COVID-19 vaccines. Nevertheless, the benefits of vaccination against SARS-CoV-2 have been substantial and probably outweigh the associated risks. Furthermore, most of the reported cases were self-limiting and had a good prognosis with available treatments. Future studies should aim to evaluate for risk factors, both ocular and systemic, which may contribute to the development of optic neuropathy after COVID-19 vaccination, and to elucidate the mechanisms underlying the development of these conditions in order to optimize their follow-up and treatment.

\section{Declarations}

Funding: None

Relevant Disclosures: The authors have no relevant financial disclosures

Conflict of interest: None.

Acknowledgements: None

Page 9/13 


\section{Ethics statement}

This report was approved by Cairo University Research Ethics Committee and followed the tenets of the Declaration of Helsinki.

\section{Patient consent}

The patient signed a written informed consent to publish this information and associated images.

\section{References}

1. Singh S, Garcia G, Shah R et al (2021) SARS-CoV-2 and its beta variant of concern infect human conjunctival epithelial cells and induce differential antiviral innate immune response.Ocul Surf.

2. Barros A, Queiruga-Pineiro J, Lozano-Sanroma J et al (2021) Small fiber neuropathy in the cornea of Covid-19 patients associated with the generation of ocular surface disease. Ocul Surf 23:40-48

3. Wang J, Li Y, Musch DC et al (2021) Progression of Myopia in School-Aged Children After COVID-19 Home Confinement. JAMA Ophthalmol 139:293-300

4. Rokohl AC, Grajewski RS, Matos PAW et al (2021) Ocular Involvement in COVID-19: Conjunctivitis and More. Klin Monbl Augenheilkd 238:555-560

5. Loffredo L, Pacella F, Pacella E et al (2020) Conjunctivitis and COVID-19: A meta-analysis. J Med Virol 92:14131414

6. Ahuja AS, Farford BA, Forouhi M et al (2020) The Ocular Manifestations of COVID-19 Through Conjunctivitis. Cureus 12:e12218

7. Elhusseiny AM, Eleiwa TK, Yacoub MS et al (2021) Relationship between screen time and dry eye symptoms in pediatric population during the COVID-19 pandemic. Ocul Surf 22:117-119

8. Eleiwa TK, Elmaghrabi A, Helal HG et al (2021) Phlyctenular Keratoconjunctivitis in a Patient With COVID-19 Infection. Cornea 40:1502-1504

9. Eleiwa T, Abdelrahman SN, ElSheikh RH et al (2021) Orbital inflammatory disease associated with COVID-19 infection. J AAPOS 25:232-234

10. Sawalha K, Adeodokun S, Kamoga GR (2020) COVID-19-Induced Acute Bilateral Optic Neuritis. J Investig Med High Impact Case Rep 8:2324709620976018

11. Eleiwa TK, Gaier ED, Haseeb A et al (2021) Adverse Ocular Events following COVID-19 Vaccination. Inflamm Res 70:1005-1009

12. Ng XL, Betzler BK, Testi I et al (2021) Ocular Adverse Events After COVID-19 Vaccination.Ocul Immunol Inflamm. $: 1-9$

13. Bayas A, Menacher M, Christ M et al (2021) Bilateral superior ophthalmic vein thrombosis, ischaemic stroke, and immune thrombocytopenia after ChAdOx1 nCoV-19 vaccination. Lancet 397:e11

14. Crnej A, Khoueir Z, Cherfan G et al (2021) Acute corneal endothelial graft rejection following COVID-19 vaccination.J Fr Ophtalmol.

15. Phylactou M, Li JO, Larkin DFP (2021) Characteristics of endothelial corneal transplant rejection following immunisation with SARS-CoV-2 messenger RNA vaccine. Br J Ophthalmol 105:893-896

16. Rabinovitch T, Ben-Arie-Weintrob Y, Hareuveni-Blum T et al (2021) Uveitis following the BNT162b2 mRNA vaccination against SARS-CoV-2 infection: a possible association.Retina. 
17. ElSheikh RH, Haseeb A, Eleiwa TK et al (2021) Acute Uveitis following COVID-19 Vaccination.Ocul Immunol Inflamm. :1-3

18. Elhusseiny AM, Sanders RN, Siddiqui MZ et al Neuroretinitis following COVID-19 vaccination.Ocul Immunol Inflamm. 2021; In press.

19. Elnahry AG, Asal ZB, Shaikh $\mathrm{N}$ et al (2021) Optic neuropathy after COVID-19 vaccination: a report of two cases.Int J Neurosci. : :1-7

20. Bohler AD, Strom ME, Sandvig KU et al (2021) Acute macular neuroretinopathy following COVID-19 vaccination. Eye (Lond).

21. Book BAJ, Schmidt B, Foerster AMH (2021) Bilateral Acute Macular Neuroretinopathy After Vaccination Against SARS-CoV-2. JAMA Ophthalmol 139:e212471

22. Endo B, Bahamon S, Martinez-Pulgarin DF (2021) Central retinal vein occlusion after mRNA SARS-CoV-2 vaccination: A case report. Indian J Ophthalmol 69:2865-2866

23. Pappaterra MC, Rivera EJ, Oliver AL (2021) Transient Oculomotor Palsy Following the Administration of the Messenger RNA-1273 Vaccine for SARS-CoV-2 Diplopia Following the COVID-19 Vaccine.J Neuroophthalmol.

24. Reyes-Capo DP, Stevens SM, Cavuoto KM (2021) Acute abducens nerve palsy following COVID-19 vaccination. J AAPOS 25:302-303

25. Khouri C, Roustit M, Cracowski JL (2021) Adverse event reporting and Bell's palsy risk after COVID-19 vaccination. Lancet Infect Dis 21:1490-1491

26. Ozonoff A, Nanishi E, Levy O (2021) Bell's palsy and SARS-CoV-2 vaccines. Lancet Infect Dis 21:450-452

27. Shibli R, Barnett O, Abu-Full Z et al (2021) Association between vaccination with the BNT162b2 mRNA COVID-19 vaccine and Bell's palsy: a population-based study. Lancet Reg Health Eur 11:100236

28. Wong ICK, Wan EYF, Chui CSL et al (2021) Adverse event reporting and Bell's palsy risk after COVID-19 vaccination Authors' reply. Lancet Infect Dis 21:1492-1493

29. Garcia-Estrada C, Gomez-Figueroa E, Alban L et al (2021) Optic neuritis after COVID-19 vaccine application.Clin Exp Neuroimmunol.

30. Girbardt C, Busch C, Al-Sheikh M et al (2021) Retinal Vascular Events after mRNA and Adenoviral-Vectored COVID19 Vaccines-A Case Series.Vaccines (Basel). ;9

31. Leber HM, Sant'Ana L, Konichi da Silva NR et al (2021) Acute Thyroiditis and Bilateral Optic Neuritis following SARS-CoV-2 Vaccination with CoronaVac: A Case Report.Ocul Immunol Inflamm. :1-7

32. Nachbor KM, Naravane AV, Adams OE et al (2021) Nonarteritic Anterior Ischemic Optic Neuropathy Associated With COVID-19 Vaccination.J Neuroophthalmol.

33. Pawar N, Maheshwari D, Ravindran M et al (2021) Ophthalmic complications of COVID-19 vaccination. Indian J Ophthalmol 69:2900-2902

34. Maleki A, Look-Why S, Manhapra A et al (2021) COVID-19 Recombinant mRNA Vaccines and Serious Ocular Inflammatory Side Effects: Real or Coincidence? J Ophthalmic Vis Res 16:490-501

35. Hattenhauer MG, Leavitt JA, Hodge DO et al (1997) Incidence of nonarteritic anterior ischemic optic neuropathy. Am J Ophthalmol 123:103-107

36. Hayreh SS (2009) Ischemic optic neuropathy. Prog Retin Eye Res 28:34-62

37. Hayreh SS (1997) Anterior ischemic optic neuropathy. Clin Neurosci 4:251-263

38. Wu Y, Zhou LM, Lou H et al (2016) The Association Between Obstructive Sleep Apnea and Nonarteritic Anterior Ischemic Optic Neuropathy: A Systematic Review and Meta-Analysis. Curr Eye Res 41:987-992

Page $11 / 13$ 
39. Aptel F, Khayi H, Pepin JL et al (2015) Association of Nonarteritic Ischemic Optic Neuropathy With Obstructive Sleep Apnea Syndrome: Consequences for Obstructive Sleep Apnea Screening and Treatment. JAMA Ophthalmol 133:797-804

40. Mojon DS, Hedges TR 3, Ehrenberg B et al (2002) Association between sleep apnea syndrome and nonarteritic anterior ischemic optic neuropathy. Arch Ophthalmol 120:601-605

41. Sharif W, Sheikh K, De Silva I et al (2017) Nonarteritic anterior ischemic optic neuropathy associated with interferon and ribavirin in a patient with hepatitis C. Am J Ophthalmol Case Rep 5:52-55

42. Purvin VA (1995) Anterior ischemic optic neuropathy secondary to interferon alfa. Arch Ophthalmol 113:10411044

43. Gupta R, Singh S, Tang R et al (2002) Anterior ischemic optic neuropathy caused by interferon alpha therapy. Am J Med 112:683-684

44. Purvin V, King R, Kawasaki A et al (2004) Anterior ischemic optic neuropathy in eyes with optic disc drusen. Arch Ophthalmol 122:48-53

45. Newman WD, Dorrell ED (1996) Anterior ischemic optic neuropathy associated with disc drusen. J Neuroophthalmol 16:7-8

46. Megur B, Megur D, Megur U et al (2014) Anterior ischemic optic neuropathy in association with optic nervehead drusen. Indian J Ophthalmol 62:829-831

47. Kawasaki A, Purvin VA, Tang R (1998) Bilateral anterior ischemic optic neuropathy following influenza vaccination. J Neuroophthalmol 18(1):56-59

48. Manasseh G, Donovan D, Shao EH et al (2014) Bilateral sequential non-arteritic anterior ischaemic optic neuropathy following repeat influenza vaccination. Case Rep Ophthalmol 5(2):267-269

49. Braithwaite T, Subramanian A, Petzold A et al (2020) Trends in Optic Neuritis Incidence and Prevalence in the UK and Association With Systemic and Neurologic Disease. JAMA Neurol 77:1514-1523

50. Lee MS, Grossman D, Arnold AC et al (2011) Incidence of nonarteritic anterior ischemic optic neuropathy: increased risk among diabetic patients. Ophthalmology 118:959-963

51. Testi I, Brandão-de-Resende C, Agrawal R, COVID-19 Vaccination Ocular Inflammatory Events Study Group et al (2022) Ocular inflammatory events following COVID-19 vaccination: a multinational case series. J Ophthalmic Inflamm Infect 12(1):4

52. Tsukii R, Kasuya Y, Makino S (2021) Nonarteritic Anterior Ischemic Optic Neuropathy following COVID-19 Vaccination: Consequence or Coincidence. Case Rep Ophthalmol Med 2021:5126254

53. Stubgen JP (2013) A literature review on optic neuritis following vaccination against virus infections. Autoimmun Rev 12:990-997

54. Levin LA, Rizzo JF 3rd, Lessell S (1996) Neural network differentiation of optic neuritis and anterior ischaemic optic neuropathy. Br J Ophthalmol 80(9):835-839

55. Elnahry AG, Elnahry GA (2020) Response to: Optic neuritis induced by 5-fluorouracil chemotherapy: case report and review of the literature. J Oncol Pharm Pract 26(3):775

56. Raina AJ, Gilbar PJ, Grewal GD et al (2020) Optic neuritis induced by 5-fluorouracil chemotherapy: Case report and review of the literature. J Oncol Pharm Pract 26(2):511-516

57. Behbehani R, Ali A, Al-Moosa A (2021) Risk factors and visual outcome of Non-Arteritic Ischemic Optic Neuropathy (NAION): Experience of a tertiary center in Kuwait. PLoS ONE 16:e0247126

58. Tsai RK, Liu YT, Su MY (1998) Risk factors of non-arteritic anterior ischemic optic neuropathy (NAION): ocular or systemic. Kaohsiung J Med Sci 14:221-225

Page 12/13 
59. Francis JH, Jaben K, Santomasso BD et al (2020) Immune Checkpoint Inhibitor-Associated Optic Neuritis. Ophthalmology 127(11):1585-1589

60. Francis JH, Jaben K, Santomasso BD et al (2020) Reply Ophthalmology 127(11):e106-e107

\section{Figures}

\section{Figure 1}

At presentation, fundus examination of the left eye revealed optic disc swelling with pallor together with blurred edges and splinter hemorrhages $(A)$. Fluorescein angiography revealed optic disc leakage with staining and scattered capillary microaneurysms (B).

\section{Figure 2}

OCT at presentation revealed left optic disc elevation with retinal nerve fiber layer thickening (A). OCT angiography showed peripapillary flow void areas with decreased vascular density indicating mild ischemia (B) [insert showing corresponding retinal nerve fiber layer thickness in each peripapillary quadrant].

\section{Figure 3}

Visual field testing of the left eye at presentation showed an inferior altitudinal field defect with enlargement of the blind spot. 